\title{
Ecclesia. Studia z Dziejów Wielkopolski
}

Том 4, 2009

\author{
DAMIAN PAŁKA \\ Uniwersytet im. Adama Mickiewicza \\ Wydział Teologiczny

\section{Idea narodu, państwa i polskości w działalności kaznodziejskiej i publicystycznej księdza Nikodema Cieszyńskiego}

The Idea of the Nation, State and Polishness in the Homiletic and Journalistic activity of Rev. Nikodem Cieszyński

Działalność kaznodziejska księdza Nikodema Ludomira Cieszyńskiego przypadła na lata dla narodu polskiego przełomowe. Urodził się 4 września $1886 \mathrm{r}$. w Koźminie ${ }^{1}$. Święcenia kapłańskie przyjął dnia 31 stycznia 1910 r., a więc jeszcze w okresie niewoli narodowej. Z kościelnej ambony przyglądał się wydarzeniom Wielkiej Wojny, która burzyła utrwalony mocą postanowień kongresu wiedeńskiego XIX-wieczny ład europejski. Jednak jego główna aktywność przypadła na trudny okres budowania polskiej państwowości, zdobywanej w czynie zbrojnym - powstanie wielkopolskie i działania wojenne w latach 1918-1921 oraz walce politycznej rozgrywającej się $\mathrm{w}$ polskim parlamencie, na polskich ulicach oraz w prasie. Kolejne lata II Rzeczpospolitej wcale nie przynosiły prostych rozwiązań trudnej sytuacji państwa i wielu narodowości je zamieszkujących, stąd nie dziwi nas obecność tematyki narodowościowej w działalności kaznodziejskiej, jak i publicystycznej księdza Cieszyńskiego. Wreszcie ostatni okres życia to lata niemieckiej okupacji, który dla księdza Cieszyńskiego zakończył się męczeńską śmiercią, podobnie jak dla setek polskich kapłanów.

Celem niniejszego artykułu jest próba usystematyzowania zagadnienia polskiego narodu w kaznodziejskiej i publicystycznej spuściźnie księdza Nikodema Cieszyńskiego. Bazę źródłową tak postawionego problemu stanowią kazania,

\footnotetext{
${ }^{1}$ Na temat życia i działalności księdza Nikodema Cieszyńskiego oraz publikacji i opracowań na jego temat zobacz szerzej: D. Kokociński, Nikodema Cieszyńskiego „Roczniki Katolickie” w latach 1923-1939. Analiza zawartości, Poznań 2009, s. 24-28.
} 
zamieszczane na łamach prasy religijnej okresu międzywojennego, drukowane zbiory kazań oraz „Roczniki Katolickie”. Całość podzielona jest na trzy części, z których w pierwszej przedstawione zostaną w zarysie źródła inspiracji i główne płaszczyzny działań pisarskich księdza Cieszyńskiego. Druga część omawia teologię dziejów narodu polskiego od czasów I wojny światowej po koniec okresu międzywojennego. Część ostatnia odnosi się do komentowanych na bieżąco problemów natury religijnej, politycznej i społecznej rozgrywających się w międzywojennej Polsce.

Jako uzupełnienie artykułu, zamieszczamy jedno z licznych publikowanych kazań księdza Cieszyńskiego. Ukazało się ono, podobnie jak wiele innych jego tekstów, nakładem własnym autora w 1936 r. i można powiedzieć, zawiera w sobie ukształtowane, zarówno pod względem stylu jak i poruszanych tematów, charakterystyczne dla stylu kaznodziejstwa Cieszyńskiego elementy.

\section{ŹRÓDŁA INSPIRACJI I GŁÓWNE POLA ZAINTERESOWAŃ}

Po święceniach pierwsze lata posługi duszpasterskiej związały autora „Roczników Katolickich" z wikariatem przy kościele Matki Boskiej Bolesnej w Poznaniu, a następnie w latach 1911-1914 przy kościele Bożego Ciała oraz przez krótki okres przy katedrze poznańskiej. W styczniu 1915 r. ksiądz Cieszyński obdarzony został prebendą przy kościele podominikańskim. Ostatecznie od 1922 r. przeszedł na rektorat kościoła Najświętszej Krwi Pana Jezusa, gdzie sprawował swój urząd do aresztowania przez władze niemieckie w $1941 \mathrm{r}^{2}$. Już od pierwszych lat swojej działalności dużą wagę przywiązywał do roli kaznodziejstwa w procesie kościelnego przepowiadania. Dlatego nie dziwi nas jego aktywność na tym polu. W tym miejscu należy zauważyć, że miejsce homiletyki wśród nauk teologicznych w tym okresie nie było jasno sprecyzowane. Postrzegano ją jako naukowo-praktyczny wstęp do właściwego sprawowania kaznodziejstwa wśród wiernych, bądź jako naukowo-praktyczne wprowadzenie do duszpasterstwa za pomocą Słowa Bożego. Polskie kaznodziejstwo przełomu stuleci czerpało wiele ze wskazań autorów podręczników teologii pastoralnej, którzy idąc za postanowieniami soboru trydenckiego przekonywali, że jego celem było nauczanie prawd wiary niezbędnych do zbawienia i ostrzeganie przed niebezpieczeństwami płynącymi ze złych czynów wiernych. Co ważne wśród zagadnień, które z ambony miały być poruszane wymieniano tylko te, które z jednej strony prowadzić miały słuchaczy do zbawienia, z drugiej wskazywać czego w życiu należy unikać. Jak wykazywali pastoraliści, wydarzenia z zakresu polityki, ekonomii, zagadnienia

\footnotetext{
${ }^{2}$ Archiwum Archidiecezjalne w Poznaniu (dalej AAP), Akta Konsystorza Arcybiskupiego (dalej KA), sygn. 12688, nlb.
} 
systemów filozoficznych, czy też zbyt trudne do zrozumienia, a nie mające na celu zbudowania wiernych nie powinny być podnoszone. Sugerowano, by nie krytykować z ambony przedstawicieli jakiejkolwiek władzy oraz nie głosić treści, które służyłyby do osiagnięcia osobistych celów, w tym popularności i poklasku u słuchaczy ${ }^{3}$. Można natomiast było odnosić się do faktów historycznych i omawiać rocznice narodowe, ale tylko w tym zakresie, w jakim wiązało się to z nauką płynącą dla czasów teraźniejszych i przyszłych ${ }^{4}$. W kazaniach należało unikać także przesady, treści watpliwych, niesprawdzonych, bedacych jedynie domysłami ${ }^{5}$. To właśnie działalności kaznodziejskiej ksiądz Cieszyński poświęcił znaczną część swojej aktywności pisarskiej. Przez pewien czas był współredaktorem „Przeglądu Homiletycznego”, a w latach 1916-1924 redagował także „Słowo Boże” będące dodatkiem do „Przewodnika Katolickiego". W zachowanych materiałach archiwalnych dotyczących jego osoby znajdujemy dwie opinie wystawione przez księży proboszczów kościołów, w których Cieszyński pełnił funkcję wikariusza. Obie odnoszą się do jego kaznodziejskiej aktywności. W 1913 r. ksiądz Leon Rankowski pisał: Na ambonę szedt chętnie. W kazaniach jego była forma ładna, gest żywy, ale myśl jeszcze słaba. Gdyby ks. Cieszyński w kierunku kaznodziejstwa zechciat zabrać się do poważnej pracy, gdyby pogtebit wiedzę swoja teologiczna i głosit zawsze Stowo Boże, a nie czczy frazes, mógtby z czasem zostać dobrym kaznodzieja, bo ma ku temu zdolności. Z kolei w styczniu 1915 r. ksiądz Franciszek Ruciński stwierdził, że był on [...] kapłanem pełnym wzniostych ideałów, gorliwy w głoszeniu słowa Bożego, z wielkq starannościq i pilnościq opracowujacy swe kazania ${ }^{7}$. Idąc niejako za wskazaniami księży proboszczów, chcąc zgłębić tę dziedzinę wiedzy zapisał się na Wydział Filozoficzny Uniwersytetu Poznańskiego, gdzie pod kierunkiem prof. Grabowskiego miał przygotować rozprawę doktorską na temat polskiego kaznodziejstwa. Mimo że niedługo potem zrezygnował z prób uzyskania stopnia naukowego, publikował liczne rozprawy i studia z zakresu homiletyki. O swej działalności kaznodziejskiej sam pisał w sposób następujący: Nie sq więc te kazania «wypocinami» jakichś żmudnych studiów ani zbiornikami dlugo gromadzonych materiałów, ile raczej swobodna wymiana myśli, wyrażonych przez człowieka, który «aetatem habet», dużo widziat $i$ styszat $w$ czasie licznych podróży [...] i ma odwage powiedzieć prawdę. Co do metody swej pracy to wyjaśniał jeszcze, że jest

\footnotetext{
${ }^{3}$ M. Biernacki, Teologia Pasterska wedtug ostatnich decyzyi Kongregacji Rzymskich i postanowień Papieskich, Warszawa-Poznań 1911, s. 300-301.

${ }^{4}$ J. S. Pelczar, Pasterz wedlug Serca Jezusowego czyli Ascetyka pasterska, Lwów 1913, s. 108.

${ }^{5}$ A. Gerstmann, Miscellanea pastoralne, t. I, Lwów 1910, s. 6-17.

${ }^{6}$ F. Lenort, Cieszyński Nikodem Ludomir, w: Encyklopedia Katolicka, t. 3, Lublin 1979, kol. 488-489; M. Banaszak, Cieszyński Nikodem Ludomir, w: Słownik polskich teologów katolickich 1918-1981, t. 5, Warszawa 1983, s. 230-231.

${ }^{7}$ AAP, KA sygn. 12688 , nlb.
} 
zwolennikiem bezwzględnej samodzielności i wrogiem przepisywania z innych autorów, co w owym czasie nie było metodą odosobnioną ${ }^{8}$ W swych pracach wymieniał nazwiska tych polskich księży, którzy w najistotniejszy sposób ukształtowali jego kaznodziejstwo, a zwłaszcza jego myślenie o narodzie i jego zadaniach. Znajdziemy wśród nich m.in. księży Piotra Skargę, Szymona Starowolskiego, Hieronima Kajsiewicza, czy Floriana Stablewskiego9.

Niewątpliwie badaczowi dziejów Kościoła ksiądz Nikodem Cieszyński znany jest jako autor „Roczników Katolickich”, które ukazywały się od 1923 r. aż do wybuchu II wojny światowej ${ }^{10}$. Wydawnictwo to jest wyjątkowe jak na owe czasy, albowiem jego autor podjął się próby przedstawienia panoramy wydarzeń z życia Kościoła katolickiego nie tylko w Europie, ale i na całym świecie. Stąd też liczne informacje dotyczące życia religijnego i problemów dotykających Kościół i jego wiernych na kontynentach obu Ameryk, czy Australii ${ }^{11}$. Dla badacza dziejów Kościoła w Polsce „Roczniki” okazują się niezwykle cennym źródłem wiedzy zarówno na temat stosunków wyznaniowych, jak i relacji pomiędzy kościelną hierarchią i władzą państwową. Sporo miejsca w „Rocznikach” ksiądz Cieszyński poświęcił tzw. „kwestii żydowskiej”, którą zajmował się również w swoich kazaniach publikowanych na łamach dodatku do lokalnego tygodnika diecezjalnego, jakim był „Przewodnik Katolicki”, jak i kazań ogłaszanych drukiem.

Oprócz wymienionych wyżej form aktywności pisarskiej wspomnieć należy również publicystykę, którą ksiądz Cieszyński uprawiał we współpracy z „Głosem Narodu”, „Wielkopolaninem Ilustrowanym” i „Dziennikiem Poznańskim”12.

${ }^{8}$ N. Cieszyński, Na przełęczy. Zbiór króciutkich kazań i rozważań na tle Ewangelij niedzielnych całego roku, Poznań 1936, s. VII-VIII.

${ }^{9}$ N. Cieszyński, Lud jako lew się podniesie. Zbiór kazań i mów kościelno-narodowych, Poznań 1921, s. 6.

${ }^{10}$ Niezwykle cenną pomocą dla badacza dziejów Kościoła jest przywoływana już praca Dariusza Kokocińskiego będąca bibliografią treści „Roczników”. Obok informacji dotyczących stanu badań nad „Rocznikami”, ich charakterystyki zarówno od strony formalnej jak i merytorycznej, otrzymujemy analityczną bibliografię „Roczników” z podziałem na kontynenty i państwa. Należy docenić żmudną pracę Kokocińskiego, dzięki której badacze historii Kościoła w okresie międzywojennym zyskali cenne narzędzie w swej pracy. D. Kokociński, Nikodema Cieszyńskiego „Roczniki katolickie"w latach 1923-1939, Poznań 2009.

${ }^{11}$ Od roku 1928 wymieniani są współpracownicy „Roczników Katolickich” m.in. księża: Stefan Grelewski, Zygmunt Pilch, Michał Klepacz, Ignacy Posadzy, Wacław Kosiński czy Jan Korzonkiewicz. Bibliografia katolickich czasopism religijnych w Polsce 1918-1944, oprac. i red. Z. Zieliński, Lublin 1981, s. 247.

${ }^{12}$ Wykaz publikacji księdza Cieszyńskiego w: Cieszyński Nikodem, w: Stownik polskich teologów, dz. cyt., s. 231-239. 


\section{TEOLOGIA DZIEJÓW NARODU I PAŃSTWA POLSKIEGO}

Dlugowiekowe zżycie się Polski z Kościotem - pisat ksiądz Cieszyński - wyryło na obliczu duchowym społeczeństwa naszego szczególne znamię katolickości. Polski inaczej sobie wystawić nie możemy, jak tylko katolicka, rdzennego, prawdziwego, petnego Polaka inaczej jak tylko katolikiem ${ }^{13}$. Te słowa opublikowane na łamach „Roczników Katolickich” stanowią niejako credo rozumienia idei narodu i państwa, które w polskich warunkach oznaczały stopienie się narodu z religią - katolicyzmem. Nie sposób omawiać kaznodziejskiej i publicystycznej działalności księdza Cieszyńskiego bez przyjęcia założenia, że Polska była i powinna pozostać katolicka, że to Bóg niejako powołał ją do bytu po latach niewoli narodowej i wydarzeniach Wielkiej Wojny.

Wydarzenia z przeszłości państwa polskiego wielokrotnie stawały się w kaznodziejstwie Cieszyńskiego kanwą opowieści, w której odbijały się bieżące problemy życia społecznego, politycznego i religijnego. W swoich kazaniach autor „Roczników Katolickich” chwalił zapisy Konstytucji 3 Maja czyniące z katolicyzmu religię narodową, a jednocześnie podkreślał, że ustawa ta nie tłamsiła ducha wolności wyznaniowej. Odwołując się do starotestamentowych motywów biblijnych krytykował króla Stanisława Augusta Poniatowskiego, który nie był tym, kim stał się Mojżesz dla narodu izraelskiego w trudnym momencie i potrafił z Bożą pomocą przeciwstawić się opozycji, na której czele stanęli Kore, Datan i Abiron. Król okazał się „miękki i zniewieściały”, zbyt słaby, dlatego sam upadł, a za nim całe państwo. Mimo niewoli „duch Pański” ciągle czuwał nad narodem, który swej wiary w Bożą Opatrzność nigdy nie zatracił. Odrodzenie Polski po Wielkiej Wojnie ksiądz Cieszyński postrzegał jako wydarzenie cudowne, a dalsze jej losy wiązał z Bożą Opatrznością ${ }^{14}$. W tych nowych warunkach, kiedy Polska ponownie zaistniała na mapach Europy, w Bożych planach miała realizować od wieków powierzone jej zadanie, „stróżowania u bram Europy”, co już niedługo ziścić się miało, gdy broniła się przed najazdem bolszewickim. Bóg swej opatrznościowej ręki od narodu jednak nie cofnął i Polska w swej misji wytrwała $^{15}$. Wizja odrodzonego państwa, opartego na zasadach religii katolickiej

\footnotetext{
${ }^{13}$ N. Cieszyński, „Roczniki Katolickie”, R. 4, 1926, s. 323. (Dalsze cytowania w nawiasie podają rok wydania danego tomu oraz numer rocznika.)

${ }_{14}$ Podczas nabożeństwa wygłoszonego dnia 7 lutego 1915 r. w Poznaniu ksiądz Cieszyński przepowiadał odrodzenie polskiej państwowości. „Wielkie cierpienie dni naszych - pisał - to wielkie odrodzenie ludzkości wielka męka dzisiejsza narodu naszego to gromka zapowiedź lepszego jutra (...). N. Cieszyński, Lud jako lew..., dz. cyt., s. 19. Podobnie w kazaniu wygłoszonym z początkiem 1918 r. w Ostrowie na ślubie brata Franciszka Ksawerego z Antoniną Witkowską, w profetycznych słowach głosił wskrzeszenie Polski w chwili, gdy świat cały drżał w posadach. N. Cieszyński, Zbiór kazań przygodnych, Poznań 1927, s. 89.

${ }^{15}$ Interpretując wynik bitwy warszawskiej wskazywał na cudowność tego wydarzenia. N. Cieszyński, Zbiór kazań przygodnych..., dz. cyt., s. 123-125, 144.
} 


\title{
Kazanie plęćdziesiąte
}

Na niedzielę XXII. po Świątkach

\section{Ojezyzna : Koseidł}

\author{
"Wtedy rzekl im: Oddajciez więc, co \\ jest cesarskiego cesarzowi, a co jest Bo- \\ żego Bogu"! (Mateusz 22, 21).
}

Żadza panowania i zysku, egoizm nieokiełznany, ciasnota i krótkowidztwo, pogańskość teoryj politycznych czy to hegeljańskiej o omnipotencji państwa, czy hipernacjonalistycznej czy komunistycznej wytworzyły w ostatnith czasie takie skłłębienie stosunków między dziećrti jẻđnej i tej samej Ojczyzny, iż trudno żyć i oddychać normalnie. Jak polip zlowrogi rozrosło się niesamowite partyjnictwo, które nietylko hamuje rótrost spoleczeństwa, ale róssadza jak dỹnañit zwartósé jego. Tóc powstaly rozmaite obozy, wrogo sobie przeciwistawione, zukosa na siebie patrżące i warczące jak złe ṗsy na siebie. Dzielą onè tak często braci tój samej rodziny, kolegów serdecznych z lawy szkolnèj, wspolwyznawców religijnych. A właśnie w czasie najpiękniejszych uroczystơści, najsoletniejszỳch świąt, najsrożej grają namiętności, najokruttuiej jèży się nienawiśé wzajemna.

Jakk na wzbutzone fale tơờskie dżiala oliwa, tak na waburzone náthiętności jolityczne winna 
202

wszelkiego uczucia ludzkiego, podupadł i spodlal, spotkala go sroga kara z rąk milościwego codopiero króla. Nie pamiętal na slowa Mędrca, jakich się uczyl w młodości-swojej: „Pomnij na ubostwo czasu obfitości, a na potrzeby ubóstwa w dzień bogactw" (Ekklk., 18, 25).

Zaiste, nieuczciwość rozlała się dzisjaj szeroko jak powódź marcowa i jak grzyb przeźera wszystkie warstwy społeczeństwa. Objawia się ona nietylko w zwyklych, ordynarnych kradzieżach, organizowanych już przez całe bandy złodziejskie czy nawet zbójeckie, nietylko $\mathrm{w}$ grubo czy subtelnie zamaskowanych oszustwach, ale i w na oko niewidocznych sposobach podchodzenia i wyzyskiwania bliźniego przez zaciaganie u niego dlugów. Zwietrzy taki sprytny człowiek gdzieś pieniądze, to już będzie chodzil około swej ofiary, lasił się, nadskakiwal, aż omota uczciwego i poczciwego właściciela sumki i wydobędzie od niego pożyczkę. Operując nią dochodzi do majątku, a wierzyciela swego miesiącami i latami zwodzi i krzywdzi. $\Lambda$ co najgorsza, nie uważa sobie tego za grzech i czuje się śmiertelnie obrażonym, jeśli właściciel „czyni z nim obrachunek" i opornego przed sąd oddaje.

Gorzej jeszcze, gdy ktoś na wystawne życie, na kolacyjki, wina, przyjęcia trwoni wlasne dochody, a nie mogąc niemi starczyć, obciąża hipoteki swojej posiadłości długami, które go wreszcie wypędza z torbami z ziemi praojców. Iluz to na oko jest dziś t. zw. szlachetnych dłużników! Postawieni jako zarządcy jakiejś instytucji na czolowem stanowisku, zaciagają ciągle nowe dlugi na budowy, przebudowy, inwestycje, niekoniecznie potrzebne, a kiedy już fale mają ich pogrążyć, opuszczają 
placówkę i następcy zostawiają obowiązek ich splacania, przyjemność przyciagania sobie i podwladnym pasa. I nie tyle dziwić się tym lekkomyślnym „organizatorom i pionierom", ile rozmaitym przełożonym, którzy takich „dłużników” powolują na wyższe stanowiska w uznaniu za to, co zdzialali, wbrew ciężarom, jakiemi obarczyli instytucje, wbrew pokrzywdzeniu następców i wierzycieli. Tak już na nice wywrócone dziś zasady chrześcijańskie w chrześcijańskiem społeczeństwie, że wystawne życic i lekkomyślne zaciąganie długów na automobile, podróże, błyszczenie, nagradza się, a skromne życie $w$ pokorze i zaciszu bez zaciagania długów, siç karze czy upokarza. A jednak prawdą pozostanie: „Lepsze jest przestawanie na malem sprawiedliwego, niż wielkie bogactwa grzesłni$k w^{\prime \prime}$. (Psalm 36, 16).

Z lekkomyślnego zaciagania dlugów $z$ uporczywego zwlekania $z$ ich spłacaniem będzie musial i ten zwierzchnik $i$ ten podwładny kiedyś zdać sprawę przed najwyższym Królem, boć nieplacenie długów jest $w$ pierwszym rzędzie krzywdzeniem. bliźniego i mnożeniem niesprawiedliwości i obłudy społecznej. Osobnik, operujący cudzemi pieniędzmi, a nie myślący o placeniu procentów umówionych ezy o uplacaniu długu w terminie, zbiera owoce $z$ cudzej pracy nieuczciwie, jest poprostu uszustem, złodziejem. Nie płacąc rachunków na czas czy to rzemieślnikowi czy kupcowi czy jakiejś instytucji, podkopuje byt pracowitych ludzi i przykłada rękę do icb zubożenia, bankructwa, zdeklasowania. O jakżeż straszne są dziś skargi krawców, którzy tysiące całe uwięzili między ludźmi możnymi, a z niedbalstwa nie kwapiącymi się 
do placenia! O, jakżeż okropne sa te skamlania robotników o zapłatę, z jaka się zạlega po rozmaitych dworach! Toć to grzechy wolające o pomstę do nieba!

Więcej! nieplacenie rachunków i długów rozprzęga wiązadła społeczne i toruje droge do ruiny spoleczeństwa. Najpierw spełpiają się słowa Mędrca: "Kto wesoly jest w biesiadach $i$ w piciu wing, w zamkach swoich zostawi spomote" (Przyp. 12, 11) na właścicielach, którzy mają na zbytki, a na zaplatę dla robotników nie mają. A powtóre, ta nieuczciwość w pałacach, dworach i fabrykach jest posiewem komunizmu. Widocznie daremne było ostrzeżenie przewrotu bulszewickiego w Rosji! $\rho$, bo i w zachodniej Europie i u nas tajemnicza ręka jakoby już pisała: „Mane, Tekel, Fares”.

Według obliczenia egzegetów "sługa" czyli wysoki urzędnik był królowi winien $58 \%$ miljona franków. A jednak milościwy pan darował mu ten ogromny dług. Nie znaczy to, żebyśmy dufni w laskawość naszych wierzycieli, mieli swobodnie brnąć w długi. To nie zachęta dla dłużników, lecz dla wierzycieli, a osobliwie dla Izb skarbowych, żeby jednak częściej mieli wzgląd na krytyczne położenie wspólezesne i okazywali ludzkość dla nieszczęśliwych, którzy zbyt często bez własnej winy uwikłali się w pęta zadłużenia. Jednak dziś przedewszystkiem niech popłynie wezwanie do płacenia rachunków i dlugów, bo one obowiązują i w sumieniu, a "zdrowie duszy $i$ świqutobliwośc sprawiedliwości lepsze sq od wszelkiego złota $i$ srebra" (Ekklk., 30, 15). Amen. 
w ciagu pierwszych lat odzyskania niepodległości - w opinii księdza Cieszyńskiego - nie została zrealizowana. Krajem targały - zwłaszcza w przeddzień wyborów parlamentarnych - waśnie i spory. Rozwijały się ruchy heretyckie przede wszystkim kościół narodowy. Propagowano socjalizm. Wszystko to mogło budzić obawę, która w ustach przywoływanego Piotra Skargi, proroczego kaznodziei na dworze Zygmunta III, pobrzmiewały złowieszczo: I ta niezgoda przywiedzie na was niewole, $w$ której wolności wasze utona $i w$ śmiech sie obró$c q$. Te słowa jednak nie miały się spełnić tym razem - przekonywał ksiądz Cieszyński - albowiem nie po to Bóg ojczyznę wskrzesił, by ją ponownie w odmętach historii zatracić ${ }^{16}$. W pierwszych latach niepodległości znajdujemy w pisarstwie Cieszyńskiego porównania odbudowy państwa polskiego do odbudowy świątyni jerozolimskiej po powrocie Żydów z niewoli babilońskiej. Praca ta postrzegana była w kategoriach mitologicznych, jako czyszczenie stajni Augiasza, czy wręcz praca syzyfowa. Szczególną rolę w tej odbudowie ksiądz Cieszyński powierzał duchowieństwu, które wzywał do czynnego zaangażowania jako realizacji swojego powołania. Księża winni wyjść z kościołów, zakrystii, klas i opanować rynki i place publiczne. Działać zarówno na polu nauki i sztuki, a także przemysłu, rzemiosła i handlu ${ }^{17}$. Nie jedyny to moment, w którym odnajdujemy porównanie historii Polski do dziejów „narodu wybranego”, a zwłaszcza tradycji związanej z wyjściem Izraelitów z Egiptu. W jednym z kazań ksiądz Cieszyński pisał: jeśli który naród to chyba polski zdolen się wczuć w potężny kantyk Mojzeszowy, co dobywajac się z głębokich pokładów natchnionej duszy wyśpiewat niebosiężna radość wolnego Izraela. Jednocześnie, jak starotestamentalni prorocy piętnował grzechy polskiego narodu, a wśród nich pijaństwo, rozpustę i chciwość ${ }^{18}$. Przekonywał, że zmartwychwstanie państwa polskiego było dopiero zaczątkiem działań nad umocnieniem państwowości. Stąd też w pisarstwie księdza Cieszyńskiego tak silnie jest obecna próba naprawy stosunków politycznych, gospodarczych czy społecznych na zasadach katolicyzmu społecznego. Musimy pamiętać, że rozwój katolickiej nauki społecznej na ziemiach polskich zyskał trwałe podstawy dopiero w początkach XX w., a okres międzywojenny odznaczył się na tym polu przede wszystkim działalnością księży Antoniego Szymańskiego, Jana Piwowarczyka, Edwarda Kozłowskiego czy ojca Jacka Woronieckiego ${ }^{19}$.

\footnotetext{
16 Tamże, s. 134-135.

${ }^{17}$ Kazanie wygłoszone w Krotoszynie podczas zjazdu koleżeńskiego w 1921 r. N. Cieszyński, Zbiór kazań przygodnych..., dz. cyt., s. 102-104.

${ }^{18}$ N. Cieszyński, Zbiór kazań przygodnych..., dz. cyt., s. 115-117.

${ }^{19}$ P. Nitecki, Zarys rozwoju katolickiej nauki społecznej w Polsce do 1989 roku, ,Społeczeństwo. Studia, prace badawcze, dokumenty z zakresu nauki społecznej Kościoła”, 1996 nr 4, s. 614. Na uwagę zasługują dwie inicjatywy, które na tym polu odnotowano w Lublinie i Poznaniu. Pierwszą z nich było powołanie w 1934 r. przy Katolickim Uniwersytecie Lubelskim Towarzystwa Naukowego, drugim założenie Katolickiej Szkoły Społecznej w Poznaniu. Te dwa ośrodki kontynuowały dawne tradycje i przyczyniały się do upowszechniania katolickiej nauki społecznej. Sze-
} 
Analizując pisarstwo księdza Cieszyńskiego można zauważyć, że włączał się on w nurt propagowania katolickich rozwiązań palących spraw polskiego narodu oraz państwa, w którym przyszło mu żyć. Stąd też piętnował nadużycia w dziedzinie gospodarczej, a zwłaszcza chciwość i wyzysk wobec najbiedniejszych mieszkańców Polski Odrodzonej ${ }^{20}$. Spoglądając na problemy życia codziennego widział konieczność tworzenia państwa, które w rozwiązywaniu problemów natury społecznej odwoływałoby się do etyki chrześcijańskiej. Nawoływał, by modlić się o Bożą opiekę, ale również tak działać, aby nie powtórzyły się czasy staropolskie, gdzie pańszczyzna była jednym z grzechów ówczesnego społeczeństwa i Boża zemsta za ucisk i wyzysk warstw najniższych nie dotknęła odradzającego się po latach niewoli narodu ${ }^{21}$.

\section{PAŃSTWO POLSKIE W OKRESIE MIĘDZYWOJENNYM - PROBLEMY I ZAGROŻENIA}

Wraz z odbudową państwa polskiego posłowie Sejmu Ustawodawczego stanęli przed ważkim problemem, jak ułożyć stosunki wyznaniowe w państwie, którego jedna trzecia obywateli nie jest Polakami i nie wyznaje katolicyzmu. Problem ten pojawił się oczywiście w kontekście przygotowywanej ustawy konstytucyjnej. W trakcie dyskusji nad jej projektem przedstawiciele Polskiego Stronnictwa Ludowego „Wyzwolenie” oraz Związku Polskich Posłów Socjalistycznych, postulowali rozdział Kościoła od państwa. Na drugim biegunie znajdowali się posłowie ugrupowań prawicowych, którzy widzieli w katolicyzmie religię większości obywateli, a co za tym idzie wyznanie, któremu należało nadać status religii panującej ${ }^{22}$. Prace Sejmu Ustawodawczego co prawda zakończyły się uchwaleniem konstytucji w marcu 1921 r., ale nie zagwarantowały Kościołowi tych praw, jakich się domagał. Regulacje prawne dotyczące związków wyznaniowych na terenie II RP zawierały się w artykułach 110-116 i 120, które gwarantowały równouprawnienie wyznań ${ }^{23}$. Kościołowi katolickiemu poświęcono

rzej na ten temat zob.: J. Majka, Katolickie szkolenie spoleczne, w: Historia katolicyzmu społecznego w Polsce 1832-1939, red. Cz. Strzeszewski, R. Bender, Warszawa 1981, s. 535-552; Cz. Strzeszewski, Rozwój chrześcijańskiej myśli społecznej w niepodległej Polsce, w: Historia katolicyzmu spotecznego..., dz. cyt., s. 275-276.

${ }^{20}$ N. Cieszyński, ,, A oni poszli za Nim”. Postaci z dziejów Męki Pańskiej. Sześć kazań pasyjnych wygłoszonych w katedrze poznańskiej 1917 roku, wyd. II zmienione, Poznań 1919, s. 8-9.

${ }^{21}$ N. Cieszyński, Zbiór króciutkich..., dz. cyt., s. 25.

${ }^{22}$ E.H. Wyczawski, Organizacja kościelna, w: Historia Kościoła w Polsce, t. 2 cz. 2, red. B. Kumor, Z Obertyński, Poznań-Warszawa 1979, s. 13.

${ }^{23} \mathrm{~W}$ zgodnej opinii historyków, konstytucja marcowa, choć gwarantowała równouprawnienie wyznań, to jednak w praktyce katolicyzm, jako religia większości obywateli państwa, cieszył się liczniejszymi przywilejami niż inne związki religijne. Por.: W. Mysłek, Przedmurze. Szkice z dzie- 
osobny artykuł 114, który stwierdzał: wyznanie rzymskokatolickie, będace religia przeważajacej większości narodu, zajmuje w państwie naczelne stanowisko wśród równouprawnionych wyznań oraz, że Kościót rzymskokatolicki rzadzi się własnymi prawami, a stosunek państwa do Kościoła będzie określony na podstawie układu ze Stolica Apostolska, który podlega ratyfikacji przez sejm. Po nieudanej próbie wprowadzenia do konstytucji z marca 1921 r. zapisu o katolicyzmie jako religii panującej oraz szkoły wyznaniowej środowiska kościelne głosiły konieczność dalszej działalności na rzecz naprawy tych niekorzystnych rozwiązań prawnych. Ksiądz Cieszyński omawiając przyjętą ustawę, stwierdził że wprowadzała ona swobodę wszystkich wyznań, nawet z uszczerbkiem dla katolicyzmu, bo stawiała je niemal na równi z innymi ${ }^{24}$.

Jednym z istotnych problemów poruszanych na łamach „Roczników Katolickich" była obecność na ziemiach polskich wyznawców prawosławia i kwestia uregulowania ich prawnego funkcjonowania. Zdaniem księdza Cieszyńskiego stosunki w polskiej cerkwi powinny zostać rozwiązane na zasadzie autokefalii, podobnie jak w Grecji, Serbii czy Rumunii. Optowanie za jej wprowadzeniem wiązało się z postulatem odrzucenia zwierzchności patriarchatu moskiewskiego nad prawosławnymi mieszkańcami państwa. Ponadto wprowadzenie autokefalii, wiązało się także z realizacją misyjnej działalności Kościoła katolickiego na Wschodzie - chodziło o teren Rosji - który stał się nie tylko ,żydowsko-pogański”, ale „wprost barbarzyńsko-ludożerczy"25. Oczywiście zasygnalizowany problem niezależności cerkwi prawosławnej w Polsce był jednym $\mathrm{z}$ wielu, które ksiądz Cieszyński uznawał za ważny dla funkcjonowania państwa i polskiego społeczeństwa. O wiele większe zagrożenie dostrzegał w ruchu socjalistycznym oraz masonerii, do której - jak przekonywał - od jakiegoś czasu dopuszczeni zostali Żydzi, którzy mieli nawet nią kierowaćé ${ }^{6}$. Komentując na bieżąco wydarzenia z życia politycznego „demaskował” wrogie dla państwa i narodu żywioły. W wyborach do parlamentu $1922 \mathrm{r}$. wygraną odniosły stronnictwa o charakterze chrześcijańskim ${ }^{27}$, ale to właśnie w tym parlamencie znalazły się siły, zdaniem księdza Cieszyńskiego, złowrogie dla naszego państwa. Budowali je przedstawi-

jów Kościoła katolickiego w II Rzeczypospolitej, Warszawa 1987, s. 66-68; Z. Zieliński, Kościót polski $w$ dziejach niewoli narodowej $i$ w Polsce odrodzonej, w: Na stolicy prymasowskiej w Gnieźnie $i$ w Poznaniu. Szkice o prymasach Polski w okresie niewoli narodowej i w II Rzeczypospolitej, red. F. Lenort, Poznań 1982, s. 27; E. H. Wyczawski, Organizacja kościelna, w: Historia Kościoła $w$ Polsce, t. 2 cz. $2 \ldots$, dz. cyt., s. 14.

${ }^{24}$ „Roczniki Katolickie”, R. 2, 1923, s. 340.

25 „Roczniki Katolickie”, R. 2, 1923, s. 339-346.

${ }^{26}$ „Roczniki Katolickie”, R. 1, 1922, s. 344-349.

${ }^{27} \mathrm{~W}$ wyborach do Sejmu najwięcej mandatów zdobyły ugrupowania prawicowe $-28 \%$, choć zaskoczeniem mógł być wynik lewicy - 22\%, a zwłaszcza Bloku Mniejszości Narodowych, który wprowadził 66 posłów (15\%). S. Sierpowski, S. Żerko, Dzieje Polski w XX wieku, Poznań 2002, s. 143. 
ciele mniejszości narodowych tworzący Blok Mniejszości Narodowych gdzie między Niemcami, Białorusinami, Rosjanami pierwsze skrzypce graja naturalnie $\dot{Z} y d z i$. Wybory te ujawniły z całą siła, że w Polsce do walki o przyszłość nie tylko państwa, ale przede wszystkim narodu stają dwa obozy: chrześcijańsko-narodowy i obóz przeciwkościelny i materialistyczny, owiany żydowsko-wywrotowymi ideami, dla narodu niebezpieczny ${ }^{28}$. To żydowskie zagrożenie ksiądz Cieszyński postrzegał jako niezwykle groźne na ziemiach polskich z uwagi na obecność w Polsce religijnego, naukowego i politycznego ruchu żydowskiego. Stąd też należało powrócić do dawnych, surowych - choć jak przekonywał nieraz bardzo mądrych zakazów średniowiecza - zasady izolacji Żydów ${ }^{29}$. Obecność żydów w chrześcijańskim społeczeństwie autor „Roczników Katolickich” podsumowywał: Tak więc dzięki swojej odrębnej strukturze psychicznej, przesyconej atmosferq niebezpiecznego mesjanizmu Izrael stanowi wśród chrześcijańskich społeczeństw odrębny naród, jakiego drugiego nie ma pod stońcem. A z winy swojego przewrotnego rewolucjonizmu rozżagwionego wprost nienawiściq do Kościoła, wyłania się on zwłaszcza w ostatnim czasie jako najniebezpieczniejszy wróg nie tylko katolicyzmu, ale w ogóle całej kultury europejskiej. I jeżeli dziś już grozi jej zagłada, to bez watpienia w zachwianiu jej żydzi najwalniejszy wzięli udziaß ${ }^{30}$.

Obok zagrożenia ze strony socjalizmu, ruchów o charakterze sekciarskim oraz Żydów wiele miejsca w swej działalności ksiądz Cieszyński poświęcił potępionej przez papieża Klemensa XII w 1738 r. masonerii. Encyklika Leona XIII Humanum genus z 1884 r., a także postanowienia Kodeksu Prawa Kanonicznego z 1917 r. uznawały szkodliwy wpływ działalności lóż masońskich na chrześcijańskie społeczeństwo i zakazywały udziału w nich katolikom ${ }^{31}$. W okresie międzywojennym polscy księża wielokrotnie omawiali szkodliwe wpływy masonerii, utożsamiając jej działalność z Żydami ${ }^{32}$. Tematyka ta często gościła na łamach „Roczników Katolickich”, gdzie omawiana była zarówno prawno-organizacyjna obecność lóż masońskich w Polsce ${ }^{33}$, stanowisko polskich hierarchów wobec masoneriii ${ }^{34}$ czy jej wpływy wśród młodzieży $y^{35}$.

28 „Roczniki Katolickie”, R. 1, 1922, s. 396-397.

${ }^{29} \mathrm{~W}$ postulatach separacji chrześcijan od Żydów przebijają motywy koncepcji asemityzmu zaproponowanej pod koniec XIX w. przez księdza Mariana Morawskiego. Zob.: M. Morawski, Asemityzm, „Przegląd Powszechny”, t. 49, 1896.

30 „Roczniki Katolickie”, R. 14, 1937, s. 181-183.

${ }^{31}$ Z. Suchecki, Kościół a masoneria, Kraków 2002, s. 22-23.; I. Grabowski, Prawo kanoniczne wedtug nowego Kodeksu, Lwów 1927, s. 767-768.

${ }^{32}$ Szerzej na ten temat zob.: D. Pałka, Kościół katolicki wobec Żydów w Polsce międzywojennej, Kraków 2006, s. 162-164.

33 „Roczniki Katolickie”, R. 5, 1927, s. 292-296.

${ }^{34}$ „Roczniki Katolickie”, R. 5, 1927, s. 291-292.

${ }^{35}$ „Roczniki Katolickie”, R. 6, 1928, s. 270-283. 
Rok 1925 dla polskiego Kościoła katolickiego okazał się niezwykle ważki i owocny. Mocą bulli cyrkumskrypcyjnej Vixdum Poloniae Unitas nastapiła reorganizacja diecezji na terenie $\mathrm{kraju}^{36}$. W tym samym roku podpisano również konkordat, który regulował stosunki pomiędzy Stolicą Apostolską a państwem polskim. Umowa zawarta 10 lutego 1925 r. została ratyfikowana przez Sejm 26 marca, a przez Senat 23 kwietnia, natomiast mocy prawnej nabrała z dniem 9 sierpnia 1925 r. Jak zauważa badacz problematyki Krzysztof Krasowski, w konkordacie biskupom, duchowienstwu i wiernym zagwarantowano swobodne i bezpośrednie porozumiewanie się ze Stolica Apostolska, a ordynariuszom petna swobode $w$ ogłaszaniu odezw i listów pasterskich. Zrezygnowano więc z jakichkolwiek ograniczeń cenzorskich $w$ stosunku do treści tych dokumentów, kazań wygłaszanych z ambony, czy też artykułów publikowanych na łamach urzędowych organów prasowych kurii diecezjalnych. [...] Konkordat polski z punktu widzenia interesów Kościoła byl sukcesem, bliżej precyzujac zapis konstytucji o jego naczelnym stanowisku wśród równouprawnionych wyznań. Późniejsza praktyka $i$ akty wykonawcze do tego układu teze te potwierdzity o tyle, że zwrot o «naczelnym stanowisku» interpretowano w sposób rozszerzajacy na korzyść Kościoła, co prowadziło do faktycznego naruszenia zasady równouprawnienia wy$z_{n a n}{ }^{37}$. Ksiądz Nikodem Cieszyński, komentując wydarzenia 1925 r. kwestii, podpisania konkordatu poświęcił osobny rozdział w swoich „Rocznikach”. Jego podpisanie uznał za ważkie, z uwagi na nienormalne pozostałości prawne po zaborcach oraz nowe okoliczności funkcjonowania Kościoła w Polsce. Dla Cieszyńskiego zawarcie umowy pomiędzy Stolicą Apostolską a rządem II RP było także świadectwem polskiego narodu przed całym światem, że państwo polskie jest katolickie i prawami rzadzić się będzie katolickimi, mimo krzykliwych sprzeciwów lewicy $i$ sekciarstwa ${ }^{38}$. Ratyfikacja umowy przez parlament, choć przeprowadzona pomyślnie dla strony kościelnej, spotkała się z opozycją lewicy parlamentarnej oraz częściowo mniejszości narodowych. Dla księdza Cieszyńskiego okazja ta po raz kolejny stała się impulsem do ukazania działalności wrogich Kościołowi sił. Wymienił wśród nich członków Polskiej Partii Socjalistycznej, hodurowców, księdza Andrzeja Huszno - twórcę polsko-katolickiego kościoła w Dąbrowie Górniczej, polskich ewangelików, czy wreszcie wolnomyślicieli. Prądy te obecne w polskiej przestrzeni publicznej, dysponujące liczną prasą ksiądz Cieszyński traktował jako „głośne ostrzeżenie” dla narodu, który poprzez przyjęcie konkordatu świadczył o istotnym dla polskości znaczeniu katolicy$\mathrm{zmu}^{39}$.

${ }^{36}$ B. Kumor, Granice metropolii i diecezji polskich (966-1939), „Archiwa, Biblioteki i Muzea Kościelne”, t. 22, 1971.

${ }^{37}$ K. Krasowski, Episkopat katolicki..., s. 188-189.

38 „Roczniki Katolickie”, R. 4, 1926, s. 246.

${ }^{39}$ Tamże, s. 250-256. 
Próbując odpowiedzieć na pytanie jak kształtowały się poglądy polityczne księdza Cieszyńskiego warto przyjrzeć się tej kwestii w perspektywie sympatii politycznych polskiego duchowieństwa w okresie międzywojennym. W polskiej historiografii brak całościowego opracowania omawiającego polityczne zaangażowanie polskiego kleru ${ }^{40}$. Opierając się na pracach poświęconych duchowieństwu diecezji łomżyńskiej, przemyskiej, chełmińskiej, sandomierskiej i katowickiej, możemy wskazać główne ugrupowania, którym księża okresu międzywojennego udzielali swego głosu.

Najsilniejszym poparciem duchowieństwa diecezji łomżyńskiej cieszyła się endecja, a jej zwolennikami byli niemal wszyscy jej księża, na czele z biskupem Stanisławem Łukomskim i biskupem pomocniczym Bernardem Dembkiem. Drugim ugrupowaniem, któremu udzielało poparcia lokalne duchowieństwo była Chrześcijańska Demokracja, a istotną rolę w tworzeniu terenowych ogniw tej formacji odegrali księża F. Haraburda, J. Kamiński i J. Łuniewski ${ }^{41}$. Podobnie sytuacja przedstawiała się w diecezji przemyskiej, gdzie większość duchowieństwa sympatyzowała z Narodową Demokracją, a ku endecji skłaniali się biskupi Józef Sebastian Pelczar, Anatol Nowak i Wojciech Tomaka. Podobnie jak na terenie diecezji łomżyńskiej, także i tutaj sporym poparciem cieszyło się Polskie Stronnictwo Chrześcijańskiej Demokracji ${ }^{42}$. Nie inaczej było na terenie diecezji chełmińskiej, której księża zasiadając w Sejmie i Senacie Polski Odrodzonej w większości byli związani z Narodową Demokracją. Cezurą dla dziejów walki politycznej na Pomorzu były wydarzenia przewrotu majowego, kiedy to w perspektywie zbliżających się kolejnych wyborów parlamentarnych, dochodziło do ostrej walki politycznej, w którą czynnie angażował się lokalny kler, w większości po stronie obozu narodowego. Ordynariusz chełmiński biskup Stanisław Okoniewski, znany ze swego prosanacyjnego nastawienia ${ }^{43}$, próbował wystapienia te hamować ${ }^{44}$. Niemalże identycznie rozkładało się poparcie duchowieństwa dla partii politycznych w diecezji sandomierskiej, gdzie najsilniejsze wpływy miała

${ }^{40}$ Na uwagę zasługuje praca Michała Pieli traktująca o udziale polskiego duchowieństwa w działalności parlamentarnej. M. Piela, Udział duchowieństwa w polskim życiu politycznym $w$ latach 1914-1924, Lublin 1994. Przyczynkiem do poznania aktywności politycznej polskiego duchowieństwa okresu międzywojennego jest artykuł piszącego te słowa. Zob.: D. Pałka, Zaangażowanie polityczne duchowieństwa katolickiego w II Rzeczypospolitej, „Społeczeństwo i Kościół”, t. 4, 2007, s. 111-122.

${ }^{41}$ W. Guzewicz, Duchowieństwo diecezji łomżyńskiej w II Rzeczypospolitej, Lublin 2003, s. 221.

${ }^{42}$ A. Szal, Duchowieństwo diecezji przemyskiej o. t. w latach 1918-1939, „Premislia Christiana", t. 3, 1989-1990, s. 163-164.

${ }^{43}$ J. Walkusz, Działalność duszpasterska biskupa Stanisława Wojciecha Okoniewskiego 19261939, „Nasza Przeszłość”, t. 85, 1995, s. 220-221.

${ }^{44}$ Tenże, Duchowieństwo katolickie diecezji chetmińskiej, Pelplin 1992, s. 336. Szerzej zob.: R. Wapiński, Endecja na Pomorzu 1920-1939, Gdańsk 1966. 
endecja. O popularności Narodowej Demokracji wśród duchowieństwa decydował jej program, głównie antykomunistyczne nastawienie ugrupowania. Jednakże z biegiem czasu na tym terenie malały szeregi duchownych popierających endecję, głównie z uwagi na głoszone przez nią hasła nacjonalistyczne. Stąd też elementem przyciagającym księży do chadecji był fakt, że partia ta otwarcie deklarowała realizację programu zgodnego z etyką katolicką i odwoływała się do nauki społecznej Kościoła ${ }^{45}$. Znacznie bardziej skomplikowana sytuacja miała miejsce na Śląsku, gdzie lokalne duchowieństwo oddawało się czynnej pracy w wielu stronnictwach politycznych. Problemy co do jedności politycznej śląskiego duchowieństwa, które do tej pory popierało endecję bądź chadecję, pojawiły się po przewrocie majowym, kiedy to wojewoda śląski Michał Grażyński, skupił wokół siebie organizacje polityczne, społeczne i zawodowe. Na Śląsku Cieszyńskim po stronie sanacji opowiedział się Związek Śląskich Katolików (ZŚK) z jego przywódcami w osobach księży Józefa Londzina (w latach 19041929) i Emanuela Grima (w latach 1929-1937). Wśród gorących zwolenników rządów obozu sanacyjnego wymienić można księży W. Siwka, R. Wallacha, R. Kulika, J. Budnego oraz A. Gałuszko. Pozyskanie przez sanację duchownych związanych z ZŚK groziło rozłamem w szeregach kleru diecezji, dlatego też ordynariusz katowicki biskup Arkadiusz Lisiecki, w tajnym okólniku z 30 stycznia 1928 r. upomniał księży, by ze spokojem i rozsądkiem podeszli do zbliżających się wyborów parlamentarnych. Jednak już kolejne wybory parlamentarne w $1930 \mathrm{r}$. pokazały, że kler diecezji nie będzie biernie obserwował zmagań politycznych, lecz czynnie zaangażuje się w kampanię wyborczą. Po śmierci w 1930 r. biskupa Lisieckiego nowym ordynariuszem został ksiądz Stanisław Adamski, czynnie zaangażowany w działalność polityczną w latach 1922-1926, kiedy to był zwolennikiem chadecji. Zamach majowy spowodował jego wycofanie się z czynnego uprawiania polityki, z czasem jednak zmienił swój stosunek do rządów sanacji, starając się w podległej mu diecezji ograniczać walkę polityczną. Po śmierci Piłsudskiego popadł jednak w konflikt z władzami państwowymi ${ }^{46}$.

$\mathrm{Na}$ terenie archidiecezji gnieźnieńskiej i poznańskiej sytuacja nie mogła przedstawiać się zgoła odmiennie, stąd nie dziwi nas fakt poparcia przez księdza Cieszyńskiego ugrupowań o charakterze prawicowym. O rządzie Wincentego Witosa, któremu prezydent Stanisław Wojciechowski powierzył funkcję premiera w 1923 r., pisał w sposób następujący: [...] kiedy wreszcie stanał przy sterze młodej $i$ wattej jeszcze nawy państwowej rząd prawicowy, poczęty nawatności cichnać, wzburzone fale układać się spokojnie, zasępione błękity ukazywać znowu

${ }^{45}$ B. Stanaszek, Duchowieństwo diecezji sandomierskiej w latach 1918-1939, Lublin 1999, s. $413-418$.

${ }^{46}$ H. Olszar, Duchowieństwo katolickie diecezji ślaskiej (katowickiej) w Drugiej Rzeczypospolitej, Katowice 2000, s. 533-538.; S. Szymecki, R. Rak, Biskup Stanisław Adamski jakiego nie zna$m y$, Katowice 2003, s. 46. 
swa jaśń - i plynęliśmy już ku pewnej, acz dalekiej jeszcze przystani ${ }^{47}$. Należy pamiętać, że Witos obejmował swoje rządy w kryzysowym dla państwa polskiego momencie. Jednym z głównych problemów, z jakim przyszło mu się zmagać była inflacja, tak charakterystyczna dla wielu europejskich państw tego okresu. Skalę problemu dobrze obrazuje kurs dolara, za którego w sierpniu płacono 246 tys. marek polskich, by w końcu października już 1612 tys. Na koniec roku dolar kosztował 6375 tys. marek polskich. Kryzys gospodarczy i inflacja wywołały w Polsce falę wystapień społecznych. Z początkiem listopada 1923 r. rząd ogłosił stan wyjątkowy w Warszawie, Krakowie, Lwowie i Łodzi. Dnia 6 listopada doszło w Krakowie do zamieszek, w wyniku których śmierć poniosło 18 cywilów i 14 żołnierzy ${ }^{48}$. Te wydarzenia odcisnęły swe piętno na stosunku władz kościelnych do ugrupowań lewicowych, albowiem to one zapowiedziały strajk na 5 listopada. Dla księdza Cieszyńskiego „wypadki krakowskie” były czymś niezrozumiałym. Pisał na ten temat: Oczom wierzyć się nie chciało, gdy w dziennikach czytało się haniebna wiadomość: Kraków opanowany przez zrewolucjonizowane tlumy! A jednak potwierdziła się rzeczywistość jeszcze straszliwsza! Więc po wsze czasy faktem historycznym, że 6 listopada 1923 roku w Polsce, rzadzonej przez prawice z chtopem Witosem na czele, $w$ Krakowie lud, podjudzony przez wywrotowe żywioły, pomordowat oficerów, rozbroit wojsko chcace zaprowadzić ład i opanowat miasto. Co ciekawe wśród przyczyn omawianych zajść nie wymienił jedynie agitatorów komunizmu i socjalizmu w Polsce. Uznał, że to obojętność wyższych warstw, związanych z Kościołem katolickim, wobec zagadnień robotniczych, przyczyniło się do ich sympatii dla ruchów lewicowych. „Wydarzenia krakowskie" uznał nie tylko za atak na etykę chrześcijańską, ale i przeciwko Kościołowi i jego hierarchii. Przestrzegał jednocześnie przed przykładem Rosji, rozpalonej bolszewizmem ${ }^{49}$.

Zakres tematyki kaznodziejskiej i publicystycznej księdza Nikodema Cieszyńskiego był bardzo szeroki. Wśród wielu tematów poruszanych przez autora „Roczników Katolickich” część z nich dotyczyła polskiego narodu i państwa, których rozumienie nie odbiegało od ówczesnego głównego nurtu w polskim katolicyzmie. Ksiądz Cieszyński wpisywał się w długą listę duchownych, którzy piętnowali słabości polskiej państwowości okresu międzywojennego i szukali możliwości naprawy stosunków społecznych. Idea posłannictwa polskiego naro-

47 „Roczniki Katolickie”, 1924, s. 365.

48 J. Faryś, II gabinet Wincentego Witosa 28.V.1923-15.XII.1923, w: Gabinety Drugiej Rzeczypospolitej, pod red. J. Farysia, J. Pajewskiego, Szczecin-Poznań 1991, s. 116-117.

49 „Roczniki Katolickie”, R. 4, 1924, s. 366-367. 
du, który miał odegrać istotną rolę w dziejach Europy, nakazywała wzywać do walki ze słabościami polskiego życia gospodarczego, społecznego i politycznego. Oczywiście proponowane rozwiązania wiązały się z rozwijaniem idei katolicyzmu społecznego, który mógł się okazać przeciwwagą dla agitacji ruchów lewicowych. Oparcie się na idei narodu, identyfikowanego z katolicyzmem, stawiało poza jego nawiasem mniejszości zamieszkujące II Rzeczpospolitą. Najbardziej radykalnie kwestia ta kształtowała się w poglądach księdza Cieszyńskiego na tzw. „kwestię żydowską”, gdzie wyznawcy judaizmu postrzegani byli jako rzecznicy osłabienia wpływów Kościoła katolickiego w polskim społeczeństwie poprzez wspieranie ruchów lewicowych czy masonerii. Jednak także w tej dziedzinie twórczość księdza Cieszyńskiego nie była odmienna od tego czym żył polski katolicyzm w omawianym okresie. Analizując pisarstwo i myśl księdza Cieszyńskiego zyskujemy wgląd $\mathrm{w}$ formację, którą ukształtowało zarówno dziedzictwo zaborów, wydarzenia Wielkiej Wojny, ale i ogólna sytuacja państwa polskiego w latach 1918-1939.

\section{SUMMARY}

The life and creative output of Rev. Nikodem Ludomir Cieszyński (1886-1942) was marked by significant events in the life of the Polish nation and state. He was born in 1886 in Koźmin but his entire pastoral ministry was connected with Poznań where he was ordained to priesthood in 1910. His activity as preacher and journalist developed in the period of national captivity, the events of the Great War and the times of interwar Poland. Subsequent significant events in the life of the Polish nation and state found their reflection in the writings of Rev. Cieszyński. His homilies, journalism, and above all editorship of the „Roczniki Katolickie” ("Catholic Annuals”) - an exceptional case in Polish ecclesial historiography - made up a large part of his activity. The regaining of independence by Poland in 1918 was portrayed by him as an extraordinary event, the intervention of Divine Providence - hence such a prominent role of the idea of a Catholic Poland in his writings. To this idea he remained faithful until the end of his life, which similarly to many Polish priests was terminated by the tragic events of the Second World War.

\section{Key words}

Church in Poland. Nation. State. Catholicism. Preaching. Rev. Nikodem Cieszyński. „Roczniki Katolickie” (“Catholic Annuals”) 